OPEN ACCESS

Approved by:

Frontiers Editorial Office, Frontiers Media SA, Switzerland

${ }^{*}$ Correspondence:

Frontiers Production Office production.office@frontiersin.org

Specialty section

This article was submitted to Personality and Social Psychology, a section of the journal Frontiers in Psychology

Received: 02 April 2019 Accepted: 03 April 2019 Published: 04 April 2019

Citation:

Frontiers Production Office (2019) Erratum: The (Not So) Changing Man: Dynamic Gender Stereotypes in Sweden. Front. Psychol. 10:892. doi: 10.3389/fpsyg.2019.00892

\section{Erratum: The (Not So) Changing Man: Dynamic Gender Stereotypes in Sweden}

\author{
Frontiers Production Office* \\ Frontiers Media SA, Lausanne, Switzerland
}

Keywords: social role theory, gender stereotypes, femininity, masculinity, agency, communion, division of labor

\section{An Erratum on}

The (Not So) Changing Man: Dynamic Gender Stereotypes in Sweden

by Gustafsson Sendén, M., Klysing, A., Lindqvist, A., and Renström, E. A. (2019). Front. Psychol. 10:37. doi: 10.3389/fpsyg.2019.00037

Due to a typesetting error, the first paragraph and heading of the section "Perceived Role Non-Traditionalism" was incorrectly placed in the section "Sweden and Gender Equality", it belongs in the section "Results" after the second paragraph. The publisher apologizes for this mistake.

The original version of this article has been updated.

Copyright $\odot 2019$ Frontiers Production Office. This is an open-access article distributed under the terms of the Creative Commons Attribution License (CC BY). The use, distribution or reproduction in other forums is permitted, provided the original author(s) and the copyright owner(s) are credited and that the original publication in this journal is cited, in accordance with accepted academic practice. No use, distribution or reproduction is permitted which does not comply with these terms. 